\title{
Beneficial soil bacterium Bacillus subtilis (GB03) augments salt tolerance of white clover
}

\author{
Qing-Qing Han ${ }^{1+}$, Xin-Pei Lü ${ }^{1+}$, Jiang-Ping Baí2, Yan Qiao², Paul W. Paré ${ }^{3}$, Suo-Min Wang ${ }^{1}$, \\ Jin-Lin Zhang ${ }^{1}{ }^{*}$, Yong-Na Wu ${ }^{1}$, Xiao-Pan Pang ${ }^{1}$, Wen-Bo Xu ${ }^{1}$ and Zhi-Liang Wang ${ }^{1}$ \\ State Key Laboratory of Grassland Agro-ecosystems, College of Pastoral Agriculture Science and Technology, Lanzhou University, Lanzhou, China \\ 2 Gansu Key Laboratory of Crop Genetic and Germplasm Enhancement, Gansu Provincial Key Laboratory of Arid Land Crop Science, College of Agronomy, Gansu \\ Agricultural University, Lanzhou, China \\ ${ }^{3}$ Department of Chemistry and Biochemistry, Texas Tech University, Lubbock, TX, USA
}

\section{Edited by:}

Vadim Volkov, London Metropolitan University, UK

\section{Reviewed by:}

Vadim Volkov, London Metropolitan University, UK

Salman Gulzar, University of Karachi, Pakistan

Yinglong Chen, The University of Western Australia, Australia

\section{*Correspondence:}

Jin-Lin Zhang, State Key Laboratory of Grassland Agro-ecosystems, College of Pastoral Agriculture Science and Technology, Lanzhou University, 768 West Jiayuguan Road, Chengguan District, Lanzhou 730020, Gansu, China e-mail: jlzhang@|zu.edu.cn

${ }^{\dagger}$ These authors have contributed equally to this work.
Soil salinity is an increasingly serious problem worldwide that reduces agricultural output potential. Selected beneficial soil bacteria can promote plant growth and augment tolerance to biotic and abiotic stresses. Bacillus subtilis strain GB03 has been shown to confer growth promotion and abiotic stress tolerance in the model plant Arabidopsis thaliana. Here we examined the effect of this beneficial soil bacterium on salt tolerance in the legume forage crop, white clover. Plants of white clover (Trifolium repens L. cultivar Huia) were grown from seeds with or without soil inoculation of the beneficial soil bacterium Bacillus subtilis GB03 supplemented with 0,50, 100, or $150 \mathrm{mM} \mathrm{NaCl}$ water into soil. Growth parameters, chlorophyll content, malondialdehyde (MDA) content and osmotic potential were monitored during the growth cycle. Endogenous $\mathrm{Na}^{+}$and $\mathrm{K}^{+}$contents were determined at the time of harvest. White clover plants grown in GB03-inoculated soil were significantly larger than non-inoculated controls with respect to shoot height, root length, plant biomass, leaf area and chlorophyll content; leaf MDA content under saline condition and leaf osmotic potential under severe salinity condition ( $150 \mathrm{mM} \mathrm{NaCl}$ ) were significantly decreased. Furthermore, GB03 significantly decreased shoot and root $\mathrm{Na}^{+}$accumulation and thereby improved $\mathrm{K}^{+} / \mathrm{Na}^{+}$ratio when GB03-inoculated plants were grown under elevated salt conditions. The results indicate that soil inoculation with GB03 promotes white clover growth under both non-saline and saline conditions by directly or indirectly regulating plant chlorophyll content, leaf osmotic potential, cell membrane integrity and ion accumulation.

\section{INTRODUCTION}

Soil salinity has a significant negative impact on global agricultural productivity, and is a particularly acute issue in both irrigated and non-irrigated areas of the world (Flowers, 2004; Zhang et al., 2010a; Kronzucker and Britto, 2011; Zhang and Shi, 2013). Most crop and forage plants that feed the global population are sensitive to high salt concentration in soils (Rengasamy, 2010; Kronzucker et al., 2013). Soil salinity promotes osmotic stress, water deficit, stomatal closure and reduced leaf expansion (Rahnama et al., 2010; James et al., 2011); moreover, soil salinity causes deficiency of essential nutrients such as $\mathrm{K}^{+}$. Elevated $\mathrm{Na}^{+}$inside plants can decrease plant photosynthetic rates and biomass accumulation (Mahajan and Tuteja, 2005; Munns and Tester, 2008; Zhang et al., 2010a; Zhang and Shi, 2013). Therefore, there is a need to find new ways to cope with the threat of global soil salinization to agriculture.

Beneficial interactions between bacteria and plants accelerate seed germination, promote growth, increase crop yields and secondary metabolites, and augment reproductive success. More recently plant-microbe interactions have been attributed to increased biotic and abiotic stress tolerance, including plant disease resistance and salt and drought tolerance (van Hulten et al., 2006; Zhang et al., 2008a; Hayat et al., 2010; Marques et al., 2010; Rudrappa et al., 2010; Medeiros et al., 2011; Cappellari et al., 2013; Diagne et al., 2013; de Zelicourta et al., 2013). Bacillus subtilis that is not toxic to humans widely exists in soils and can produce a wealth of antibacterial substances including lipopeptides, polypeptides, and phospholipids (Stein et al., 2002). Recently, Medeiros et al. (2011) found that transcriptional profiling in cotton was linked with Bacillus subtilis (UFLA285) which promoted biotic-stress tolerance. Zhang et al. (2011) found that a bioorganic fertilizer could effectively control banana wilt by strong colonization of Bacillus subtilis N11. B. subtilis strain GB03 that emits a complex blend of volatile organic compounds (VOCs) enhances growth and abiotic stress tolerance in Arabidopsis (Ryu et al., 2004; Farag et al., 2006). A bouquet of over 25 bacterial volatile odors have been identified that trigger differential expression of approximately 600 Arabidopsis transcripts related to cell wall modifications, primary and secondary metabolism, stress responses, hormone regulation and 
other expressed proteins (Zhang et al., 2007). In Arabidopsis, GB03 regulates auxin homeostasis and cell expansion (Zhang et al., 2007), augments photosynthesis by decreasing glucose sensing and ABA levels (Zhang et al., 2008b); promotes salt tolerance as well as reduces total $\mathrm{Na}^{+}$by regulating tissue specific expression of AtHKT1 (Zhang et al., 2008a). GB03 has also been shown to stimulate iron acquisition and increased photosynthetic capacity (Zhang et al., 2009). More recently GB03 has been found to improve osmotic-stress tolerance by elevating levels of endogenous osmoprotectants (Zhang et al., 2010b). With such beneficial plant responses activated by GB03, a legume forage crop is now being examined as to how it responds to this beneficial microbe.

White clover (Trifolium repens L.) is an important forage crop worldwide. Like many forage crops, white clover is sensitive to soil salinity (Rogers et al., 1997). Salt stress can decrease both above-ground growth and the number of root nodules that in turn compromise nitrogen fixation and soil fertility (Acharya et al., 2011). Since GB03 promotes growth and salt tolerance in Arabidopsis, the question of how GB03 improves growth and salt tolerance in the salt-sensitive forage crop white clover was addressed. The aim of current work was to evaluate the efficiency of Bacillus subtilis GB03 for growth promotion and salt tolerance in white clover.

\section{MATERIALS AND METHODS BACTERIAL SUSPENSION CULTURE}

Bacillus subtilis strain GB03 was streaked onto LB agar plates and incubated at $28^{\circ} \mathrm{C}$ without light for $24 \mathrm{~h}$ (The bacterium strain was presented by Professor Paul W. Paré at Texas Tech University, USA). Bacterial cells were then harvested from LB agar plates, transferred into liquid $\mathrm{LB}$ media and cultured at $28^{\circ} \mathrm{C}$ with $250 \mathrm{rpm}$ rotation to yield $10^{9}$ colony forming units $(\mathrm{CFU}) \mathrm{mL}^{-1}$, as determined by optical density and serial dilutions (Zhang et al., 2008a).

\section{PLANT GROWTH AND TREATMENTS}

White clover (Trifolium repens L. cultivar Huia) seeds were surface sterilized with $2 \% \mathrm{NaClO}$ for 1 min followed by $70 \%$ ethanol for $10 \mathrm{~min}$, and rinsed with sterile water five times (The white clover seeds was presented by Dr. Wanhai Zhou at Gansu Agricultural University, China). Seeds were then sown in presterilized plastic pots (diameter $20 \mathrm{~cm}$, depth $22 \mathrm{~cm}, 10$ seeds/pot with eight replicates) containing $600 \mathrm{~g}$ of heat-sterilized $\left(95^{\circ} \mathrm{C}\right.$, $48 \mathrm{~h}$ ) vermiculite and soil mix (1:1) watered with half strength Hoagland's nutrient solution $\left(5 \mathrm{mM} \mathrm{KNO}_{3}, 1 \mathrm{mM} \mathrm{NH} \mathrm{H}_{2} \mathrm{PO}_{4}\right.$, $0.5 \mathrm{mM} \mathrm{Ca}\left(\mathrm{NO}_{3}\right)_{2}, 0.5 \mathrm{mM} \mathrm{MgSO}_{4}, 60 \mu \mathrm{M}$ Fe-citrate, $92 \mu \mathrm{M}$ $\mathrm{H}_{3} \mathrm{BO}_{3}, 18 \mu \mathrm{M} \mathrm{MnCl}_{2} \cdot 4 \mathrm{H}_{2} \mathrm{O}, 1.6 \mu \mathrm{M} \mathrm{ZnSO}_{4} \cdot 7 \mathrm{H}_{2} \mathrm{O}, 0.6 \mu \mathrm{M}$ $\mathrm{CuSO}_{4} \cdot 5 \mathrm{H}_{2} \mathrm{O}$, and $\left.0.7 \mu \mathrm{M}\left(\mathrm{NH}_{4}\right)_{6} \mathrm{Mo}_{7} \mathrm{O}_{24} \cdot 4 \mathrm{H}_{2} \mathrm{O}\right)$. Each pot was watered with nutrient solution $(400 \mathrm{~mL})$ once per week. After germination, six uniform seedlings per pot were selected for continued growth and inoculated directly to the soil with $1 \mathrm{~mL}$ bacterial suspension culture as inoculation treatment or $1 \mathrm{~mL}$ liquid LB medium as a control. For salt stress treatments, seedlings were watered with $0,50,100$, and $150 \mathrm{mM} \mathrm{NaCl}$ present in the nutrient solution. Each treatment contained eight pots as replications. Plants were grown in a glasshouse at the temperature regulated to around $28^{\circ} \mathrm{C}$ during the day and $22^{\circ} \mathrm{C}$ at night. Relative humidity averaged 65 and 75\% for day and night periods, respectively, with natural photoperiod and light intensity.

\section{PLANT BIOMASS AND PHYSIOLOGICAL MEASUREMENTS}

Sixty-day old plants were used for plant growth measurements and physiological index determination. Whole plant leaves were harvested to count leaf number per plant, measure leaf area using a leaf area meter (Epson Perfection 4870 Photo scanner, Epson America Inc., Long Beach, CA, USA) (Ma et al., 2012). Average area per leaf was calculated from leaf area per plant divided by leaf number per plant.

Plants were removed from the pots and roots were water rinsed to remove attached soil. Shoot height and root length (root depth) were measured by a ruler. Then, root and shoot were separated and blotted gently. Fresh weights were determined immediately and samples were oven dried at $80^{\circ} \mathrm{C}$ for 2 day for dry weight measurements.

Leaf chlorophyll content was estimated according to Porra et al. (1989). Fresh leaf samples were ground thoroughly with $80 \%$ acetone in the dark and centrifuged at $9000 \mathrm{~g}$ for $10 \mathrm{~min}$ at $4^{\circ} \mathrm{C}$. Absorbance reading (UV-2102C Spectrophotometer, Unico Instrument Co., Ltd, Shanghai, China) at 645 and $663 \mathrm{~nm}$ for collected supernatant was used to estimate total chlorophyll content based on chlorophyll equations of Porra et al. (1989).
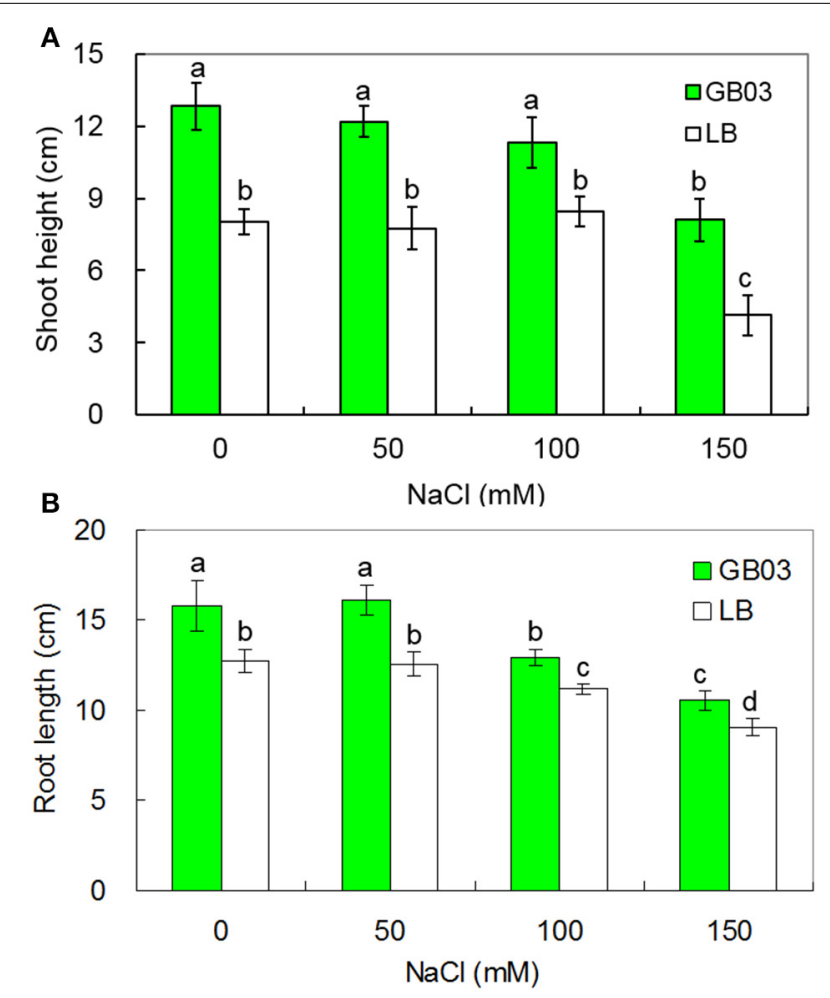

FIGURE 1 | Effects of GB03 bacterization on shoot height (A) and root length (B) of white clover under various concentrations of $\mathrm{NaCl}$. Values are means and bars indicate SDs $(n=8)$. Columns with different letters indicate significant difference at $P<0.05$ (Duncan test). 
To probe oxidative stress the biomarker malondialdehyde (MDA) was extracted and measured spectrophotometrically using a thiobarbituric acid (TBA) protocol (Bao et al., 2009). Absorbance was determined at 450, 532, and $600 \mathrm{~nm}$ using a UV spectrophotometer (UV-2102C, Unico Instrument Co., Ltd, Shanghai, China).

Leaf osmotic potential ( $\Psi \mathrm{s}$ ) was measured according to $\mathrm{Ma}$ et al. (2012). Fresh leaf samples were frozen in liquid nitrogen. Cell sap was collected by thawing slowly and then $\Psi$ s was determined using a cryoscopic osmometer (Osmomat-030, Gonotec $\mathrm{GmbH}$, Berlin, Germany) at $25^{\circ} \mathrm{C}$. The readings $\left(\mathrm{mol} \cdot \mathrm{L}^{-1}\right)$ were used to calculate the solute potential $(\Psi \mathrm{s})$ in $\mathrm{MPa}$ with the formula $\Psi \mathrm{s}=-$ The readings $\times R \times T$, here $R=0.008314 \mathrm{MPa} \cdot \mathrm{L}$. $\mathrm{mol}^{-1} \cdot \mathrm{K}^{-1}$ and $T=298.8 \mathrm{~K}$ (Ma et al., 2012).

\section{ION ANALYSIS}

$\mathrm{Na}^{+}$and $\mathrm{K}^{+}$contents were measured according to the method described by Wang et al. (2007). Roots were washed twice for eight min in ice-cold $20 \mathrm{mM} \mathrm{CaCl}_{2}$ to exchange cell wall-bound $\mathrm{K}^{+}$and $\mathrm{Na}^{+}$and the shoots were rinsed in deionized water to remove surface salts. Root and shoot were separated and samples oven dried at $70^{\circ} \mathrm{C}$ for 2 day. $\mathrm{Na}^{+}$and $\mathrm{K}^{+}$were extracted from dried plant tissues in $100 \mathrm{mM}$ acetic acid at $90^{\circ} \mathrm{C}$ for $2 \mathrm{~h}$. Ion analysis was performed using an atomic absorption spectrophotometer (2655-00, Cole-Parmer Instrument Co., Vernon Hills, IL, USA).

\section{DATA ANALYSIS}

Results of the growth, physiological index, ion contents and ion ratio were presented as means with standard deviations $(n=8)$.
Statistical analyses, One-Way ANOVA and Duncan's multiple range tests, were performed.

\section{RESULTS}

\section{BACILLUS SUBTILIS GB03 PROMOTED WHITE CLOVER GROWTH}

Bacillus subtilis GB03 enhanced both shoot height and root length of white clover under both non-saline conditions and salinity stress (Figure 1 and Supplementary Figure 1). Shoot height was increased by $60.1 \%(P<0.05)$ under non-saline conditions; compared to corresponding media control, GB03 significantly improved shoot height by 57.4\% $(P<0.01)$, 33.7\% $(P<0.05)$, and $95.6 \%(P<0.01)$ at 50,100 , and $150 \mathrm{mM} \mathrm{NaCl}$ treatments, respectively (Figure 1A). Root length was increased by 23.9\% $(P<0.05)$ under non-saline conditions; compared to corresponding media control, GB03 significantly improved root length by $28.0 \%(P<0.01), 15.4 \%(P<0.01)$, and $16.9 \%(P<$ 0.05 ) with 50,100 , and $150 \mathrm{mM} \mathrm{NaCl}$ treatments, respectively (Figure 1B).

GB03 increased plant biomass of white clover under both non-saline conditions and salinity stress (Figure 2). Shoot fresh weight was increased 4.1 -fold $(P<0.05)$ under non-saline conditions; compared to corresponding media control, GB03 significantly improved shoot fresh weight by 5.5 -fold $(P<0.05)$, 6.9-fold $(P<0.01)$, and 3.0-fold $(P<0.05)$ with 50, 100, and $150 \mathrm{mM} \mathrm{NaCl}$ treatment, respectively (Figure 2A). Shoot dry weight was increased by 4.0 -fold $(P<0.05)$ under non-saline conditions; compared to corresponding media control, GB03 significantly improved shoot dry weight by 4.9 -fold $(P<0.05)$, 6.4-fold $(P<0.01)$, and 3.2-fold $(P<0.05)$ with 50, 100, and
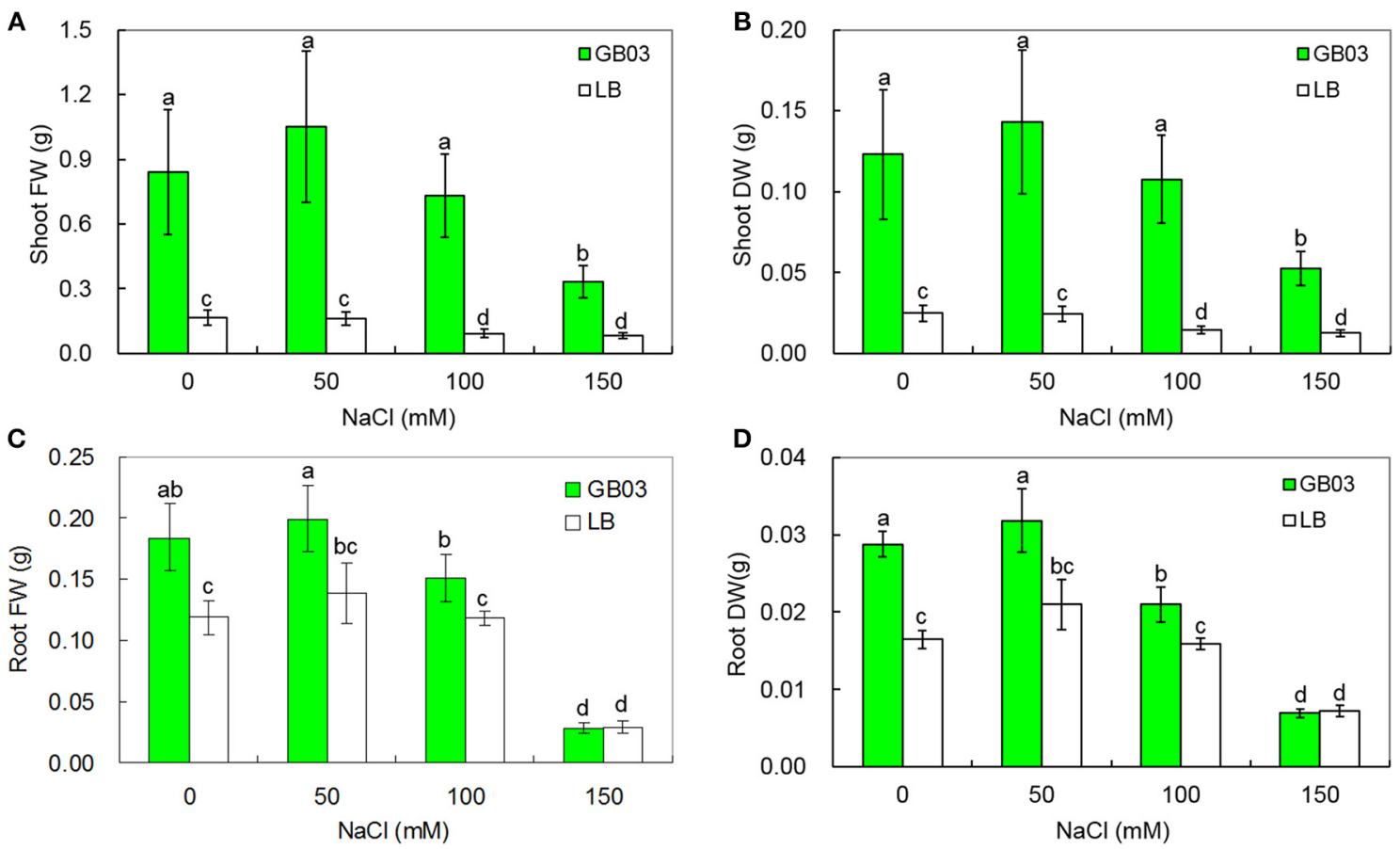

FIGURE 2 | Effects of GB03 bacterization on plant growth of white clover under various concentrations of $\mathrm{NaCl}$. (A) shoot fresh weight, (B) shoot dry weight, (C) root fresh weight, and (D) root

dry weight. Values are means and bars indicate SDs $(n=8)$. Columns with different letters indicate significant difference at $P<0.05$ (Duncan test). 
$150 \mathrm{mM} \mathrm{NaCl}$ treatment, respectively (Figure 2B). Root fresh weight was increased by $55.0 \%(P<0.05)$ under non-saline conditions; compared to corresponding media control, GB03 significantly improved shoot dry weight by $44.1 \%(P<0.05)$ and $27.7 \%(P<0.05)$ at 50 and $100 \mathrm{mM} \mathrm{NaCl}$ treatment, respectively (Figure 2C). Root dry weight was increased by $74.7 \%(P<0.01)$ under non-saline conditions; compared to corresponding media control, GB03 significantly improved shoot dry weight by $51.7 \%$ $(P<0.01)$ and $32.5 \%(P<0.05)$ at 50 and $100 \mathrm{mM} \mathrm{NaCl}$ treatment, respectively (Figure 2D). GB03 had no significant effects on root fresh and dry weights under $150 \mathrm{mM} \mathrm{NaCl}$ stress.

\section{GB03 INCREASED LEAF AREA AND CHLOROPHYLL CONTENT}

GB03 promoted leaf growth under both non-saline and salinity stress conditions (Figure 3). Leaf area per plant was increased by 3.1-fold $(P<0.05)$ under non-saline conditions; compared to corresponding media control, GB03 significantly increased leaf area per plant by 5.7 -fold $(P<0.05), 7.8$-fold $(P<0.01)$, and 1.5 -fold $(P<0.05)$ with 50,100 , and $150 \mathrm{mM} \mathrm{NaCl}$ treatment, respectively (Figure 3A). Leaf number per plant was increased by $84.2 \%(P<0.05)$ under non-saline conditions; compared to corresponding media control, GB03 significantly elevated leaf number per plant by $142.1 \%(P<0.05)$ and $107.7 \%(P<0.05)$ with 50 and $100 \mathrm{mM} \mathrm{NaCl}$ treatments, respectively (Figure 3B). Average area per leaf was increased by $125.6 \%(P<0.05)$ under non-saline conditions; compared to corresponding media control, GB03 significantly improved average area per leaf by $159.4 \%$ $(P<0.01)$, 334.5\% $(P<0.01)$, and $81.5 \%(P<0.01)$ with 50 , 100 , and $150 \mathrm{mM} \mathrm{NaCl}$ treatments, respectively (Figure 3C).

In addition to promoting leaf growth, Bacillus subtilis GB03 increased leaf chlorophyll content under both non-saline and salinity stress (Figure 4). Leaf chlorophyll content rose by $36.0 \%(P<0.01)$ under non-saline condition; compared to corresponding media control, GB03 significantly increased leaf chlorophyll content by $34.3 \%(P<0.01), 37.5 \%(P<0.01)$, and $57.4 \%(P<0.01)$ with 50,100 , and $150 \mathrm{mM} \mathrm{NaCl}$ treatments, respectively (Figure 4 ).

\section{GB03 REDUCED LEAF OSMOTIC POTENTIAL UNDER HIGHER SALINITY CONDITION}

At lower salt concentration $(0,50$, and $100 \mathrm{mM} \mathrm{NaCl})$, compared with the controls, GB03 had no significant effect on leaf osmotic potential; however, under higher salt concentration $(150 \mathrm{mM}$ $\mathrm{NaCl}$ ), GB03 significantly decreased leaf osmotic potential of white clover by $46.7 \%(P<0.05)$ (Figure 5).

\section{GB03 REDUCED LEAF MALONDIALDEHYDE (MDA) CONTENT UNDER SALINITY CONDITIONS}

The results indicated that GB03 reduced leaf MDA content under both non-saline conditions and salinity stress (Figure 6). Leaf MDA content was not changed under non-saline conditions; however, compared to corresponding media control, GB03 significantly reduced leaf MDA content by 52.7\% $(P<0.01)$, $56.8 \%(P<0.01)$, and 53.8\% $(P<0.05)$ with 50,100, and $150 \mathrm{mM} \mathrm{NaCl}$ treatments, respectively (Figure 6), thus, oxidative stress tolerance and integrity of the cell membrane as measured by the biomarker MDA were both favorably regulated by GB03.

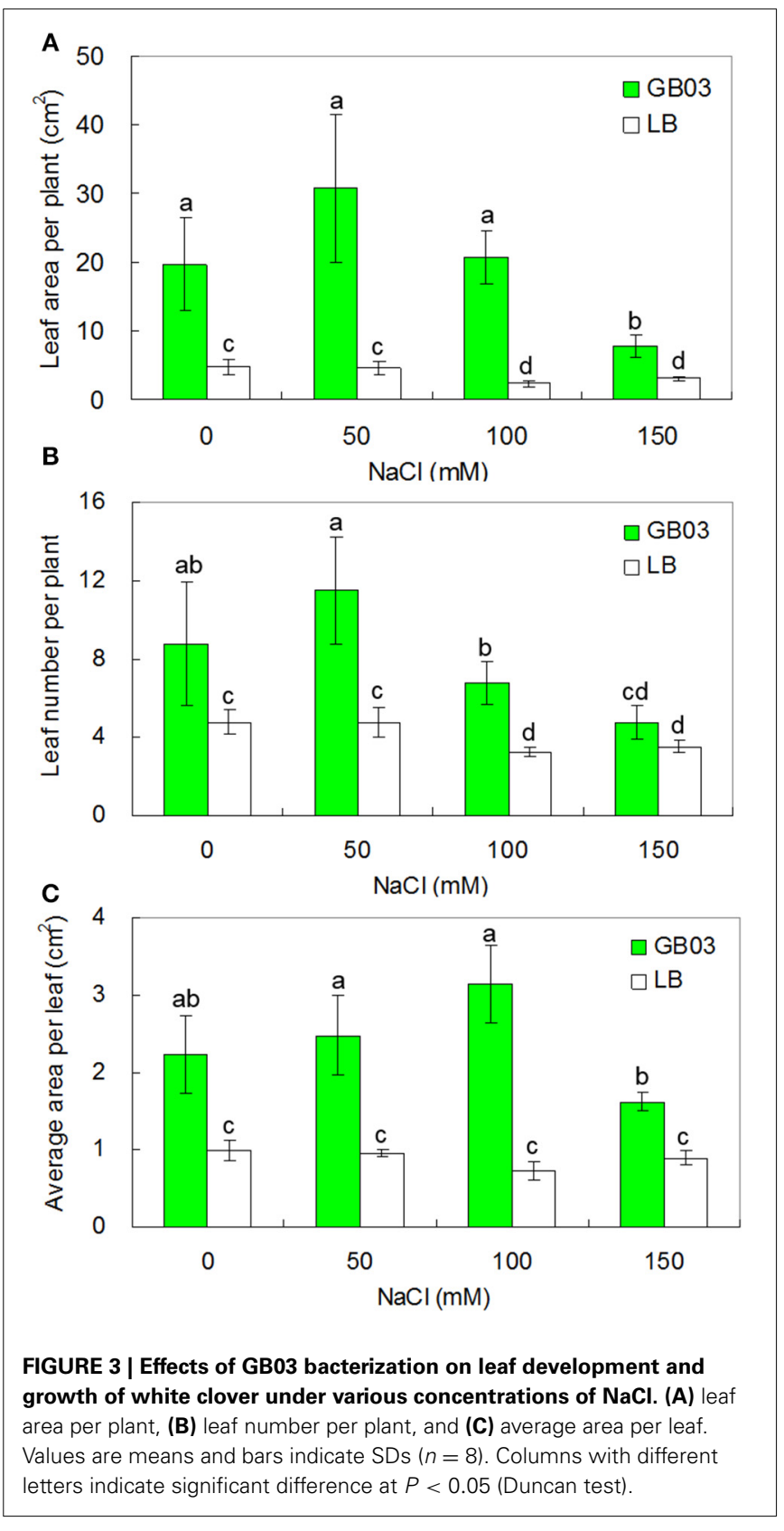

\section{GB03 REDUCED SODIUM ACCUMULATION UNDER SALINITY CONDITIONS}

To test whether GB03 inoculation resulted in altered ion accumulation in white clover under various salinity conditions, endogenous $\mathrm{Na}^{+}$and $\mathrm{K}^{+}$content was measured in the 0,50 , 100 , and $150 \mathrm{mM} \mathrm{NaCl}$ treatments. $\mathrm{K}^{+}$accumulation was uneffected by GB03 inoculation (Figures 7A,B). However, endogenous $\mathrm{Na}^{+}$accumulation was reduced significantly. Compared to the media control, GB03 significantly decreased shoot $\mathrm{Na}^{+}$content by $40.7 \%(P<0.01), 22.5 \%(P<0.01)$, and $26.3 \%(P<$ $0.01)$, as well as root $\mathrm{Na}^{+}$content by $27.1 \%(P<0.05), 39.7 \%$ $(P<0.01)$, and $40.7 \%(P<0.01)$ with 50,100 , and $150 \mathrm{mM}$ $\mathrm{NaCl}$ treatments, respectively (Figures 7C,D). 


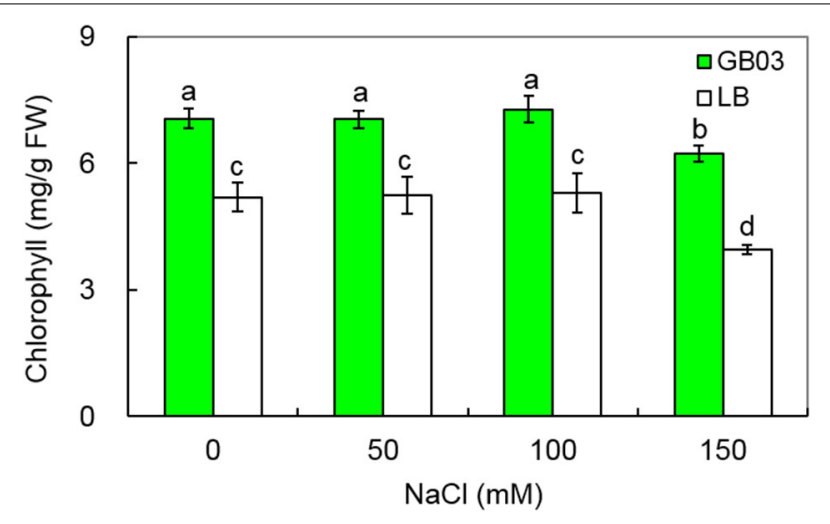

FIGURE 4 | Effects of GB03 bacterization on total chlorophyll content of white clover under various concentrations of $\mathbf{N a C l}$. Values are means and bars indicate SDs ( $n=8)$. Columns with different letters indicate significant difference at $P<0.05$ (Duncan test).

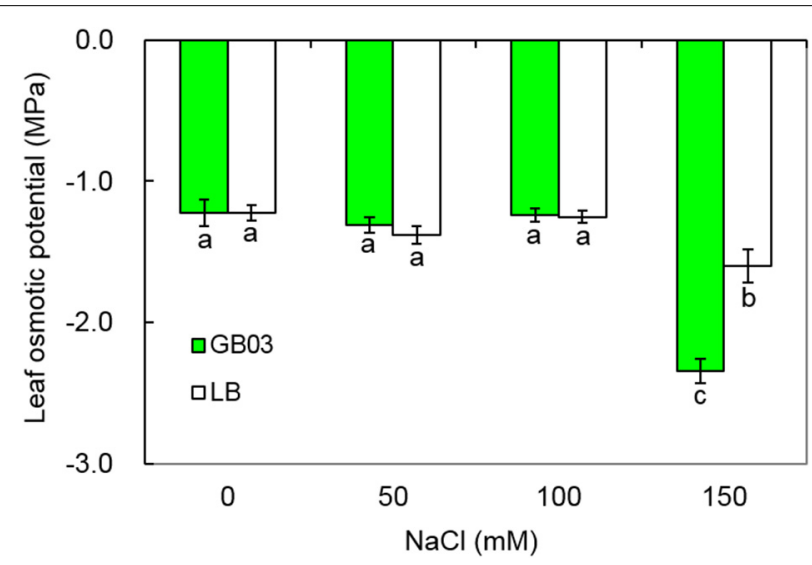

FIGURE 5 | Effects of GB03 bacterization on leaf osmotic potential of white clover under various concentrations of $\mathrm{NaCl}$. Values are means and bars indicate SDs ( $n=8)$. Columns with different letters indicate significant difference at $P<0.05$ (Duncan test).

$\mathrm{K}^{+} / \mathrm{Na}^{+}$ratios were also significantly improved by GB03 inoculation with 50,100 , and $150 \mathrm{mM} \mathrm{NaCl}$ treatments. Compared to corresponding media control, Shoot $\mathrm{K}^{+} / \mathrm{Na}^{+}$ratios increased by $78.6 \%(P<0.01), 32.0 \%(P<0.05)$, and $39.7 \%(P<0.05)$ as well as root $\mathrm{K}^{+} / \mathrm{Na}^{+}$ratios by $34.6 \%(P<0.05), 82.2 \%$ $(P<0.01)$, and $66.2 \%(P<0.01)$ under soil salinity conditions of 50, 100, and $150 \mathrm{mM} \mathrm{NaCl}$, respectively (Table $\mathbf{1}$ ).

\section{DISCUSSION}

\section{INFLUENCE OF BACILLUS SUBTILIS GBO3 ON GROWTH OF WHITE CLOVER UNDER SALINE CONDITION}

Beneficial soil bacteria promoted plant growth of many plant species (Bashan et al., 2000; Gray and Smith, 2005; Xie et al., 2009; Paré et al., 2011). Under salinity stress, inducible plant growth promotion mediated by beneficial soil bacteria has also been observed in several cultivated and wild plant species including dwarf saltwort (Salicornia bigelovii) (Bashan et al., 2000), tomato

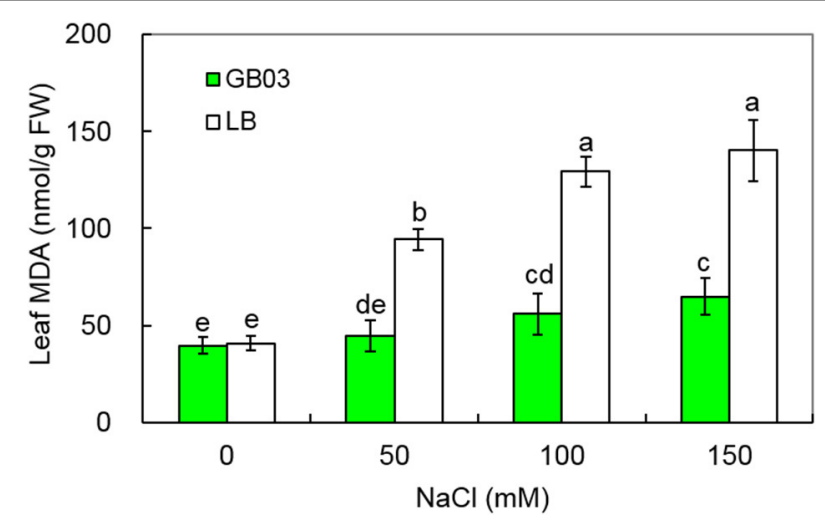

FIGURE 6 | Effects of GB03 bacterization on leaf malondialdehyde (MDA) content of white clover under various concentrations of $\mathrm{NaCl}$. Values are means and bars indicate SDs $(n=8)$. Columns with different letters indicate significant difference at $P<0.05$ (Duncan test).

(Lycopersicon esculentum) (Mayak et al., 2004), chickpea (Cicer arietinum) (Mhadhbi et al., 2004), alfalfa (Medicago sativa) (Ibragimova et al., 2006), common glasswort (Salicornia europea) (Ozawa et al., 2007), maize (Zea mays) (Bano and Fatima, 2009), and wheat (Triticum aestivum) (Tiwari et al., 2011). The growth promotion of white clover by GB03 inoculation in soil evaluated in the present study is consistent with previous reports in Arabidopsis (Zhang et al., 2007, 2008a,b, 2010b; Xie et al., 2009; Paré et al., 2011). Interestingly, our results indicated that GB03 is a more efficient promoter of shoot growth than root growth in white clover, especially under salt exposure $(50,100$, and $150 \mathrm{mM} \mathrm{NaCl})$. Whether GB03 promotes growth of white clover by enhancing nitrogen fixation and the coordination between nitrogen-fixing bacteria and Bacillus subtilis (GB03) in the rhizosphere remain to be investigated.

Leaf development plays an important role in plant production since it affects the area available for photosynthesis, which is strongly related to plant growth and biomass accumulation (Gutierrez-Boem and Thomas, 1998; Battie-Laclau et al., 2013). In our study, GB03 inoculation significantly increased leaf area per plant, leaf number per plant, and thereby average area per leaf in white clover. Leaf chlorophyll content is also an important physiological trait directly linked to photosynthesis rate in plants (Ma et al., 2012). Previous studies showed that plants grown under salinity conditions produced less chlorophyll and dry matter than those without salinity stress due to chlorophyll peroxidation (Hernandez et al., 1995; Zayed and Zeid, 1998; Lunde et al., 2007; Tuna et al., 2008; Barry, 2009). Zhang et al. (2008b) found that GB03 augments photosynthetic capacity by increasing photosynthetic efficiency and chlorophyll content in Arabidopsis. With white clover, GB03 significantly improved leaf chlorophyll content under both non-saline and salinity conditions $(50,100$, and $150 \mathrm{mM} \mathrm{NaCl})$.

\section{GB03 AMELIORATED LEAF OSMOTIC ADJUSTMENT ABILITY AND ALLEVIATED CELL MEMBRANE DAMAGE UNDER SALINE CONDITIONS}

When plants are exposed to saline or drought conditions, osmotic stress rapidly follows (Munns and Tester, 2008). Salt stress reduces 

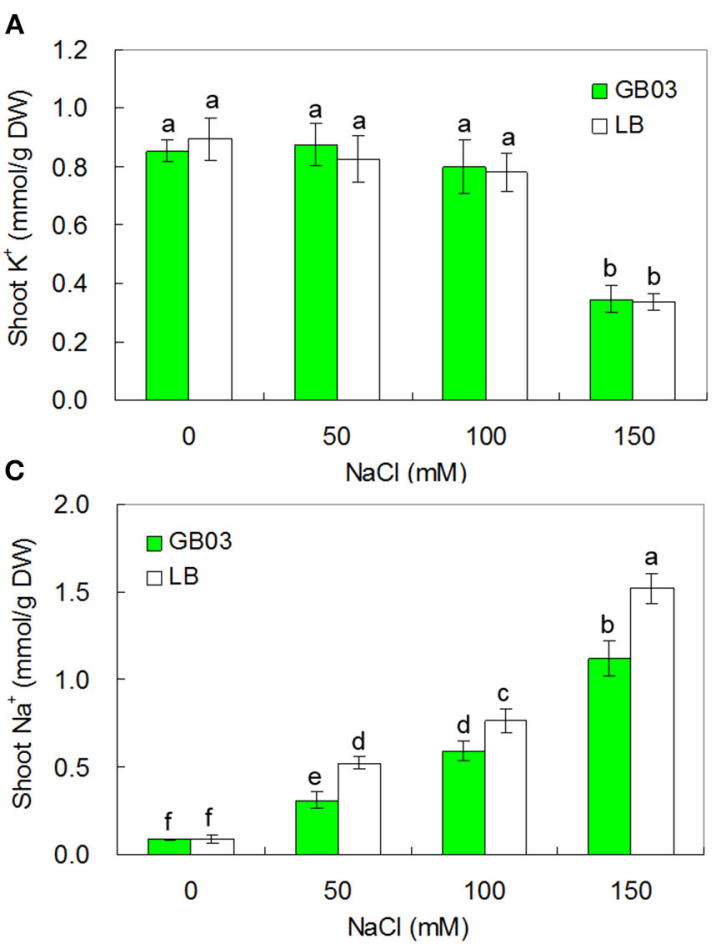

FIGURE 7 | Effects of GB03 bacterization on ion contents of white clover under various concentrations of $\mathrm{NaCl}$. (A) shoot $\mathrm{K}^{+}$ content, (B) root $\mathrm{K}^{+}$content, (C) shoot $\mathrm{Na}^{+}$content, (D) root $\mathrm{Na}^{+}$
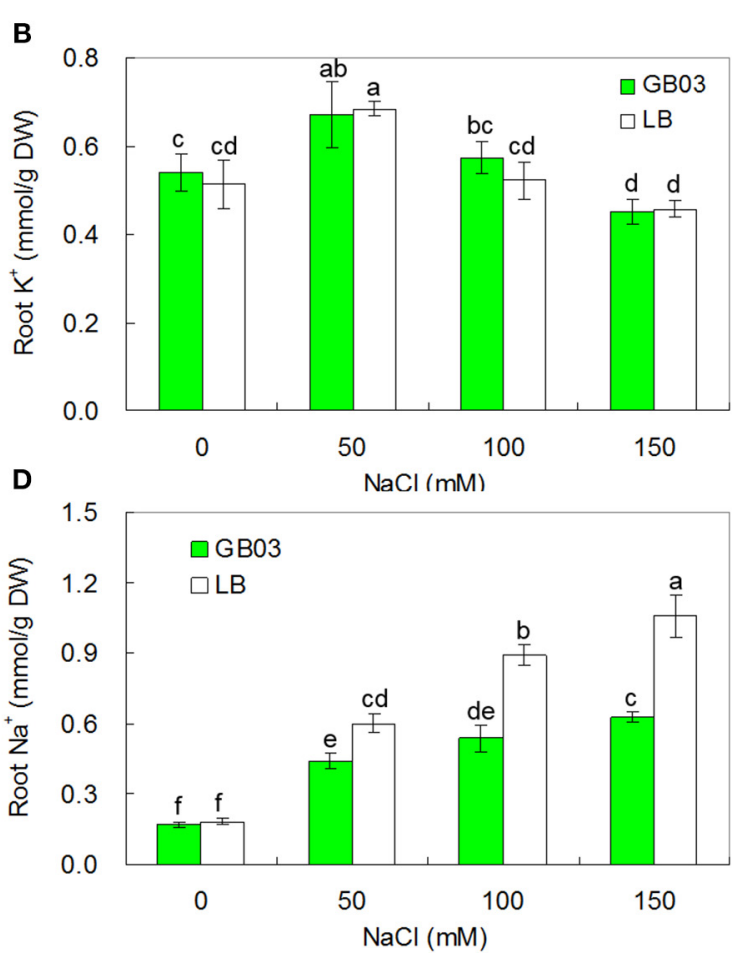

content. Values are means and bars indicate SDs $(n=8)$. Columns with different letters indicate significant difference at $P<0.05$ (Duncan test).
Table 1 | Effects of GB03 bacterization on $\mathrm{K}^{+} / \mathrm{Na}^{+}$ratio in shoot and root of white clover under various concentrations of $\mathrm{NaCl}$.

\begin{tabular}{lcclcc}
\hline \multirow{2}{*}{ NaCl (mM) } & \multicolumn{2}{c}{ Shoots } & & \multicolumn{2}{c}{ Roots } \\
\cline { 2 - 3 } \cline { 5 - 6 } & GB03 & LB & & GB03 & LB \\
\hline 0 & $9.87 \pm 0.42 \mathrm{a}$ & $9.81 \pm 0.80 \mathrm{a}$ & & $3.13 \pm 0.25 \mathrm{a}$ & $2.81 \pm 0.30 \mathrm{a}$ \\
50 & $2.81 \pm 0.24 \mathrm{~b}$ & $1.58 \pm 0.15 \mathrm{c}$ & & $1.53 \pm 0.17 \mathrm{~b}$ & $1.14 \pm 0.03 \mathrm{c}$ \\
100 & $1.35 \pm 0.15 \mathrm{~cd}$ & $1.03 \pm 0.09 \mathrm{~d}$ & & $1.07 \pm 0.07 \mathrm{c}$ & $0.59 \pm 0.05 \mathrm{e}$ \\
150 & $0.31 \pm 0.04 \mathrm{e}$ & $0.22 \pm 0.02 \mathrm{e}$ & & $0.72 \pm 0.05 \mathrm{~d}$ & $0.43 \pm 0.02 \mathrm{f}$
\end{tabular}

Values are means $\pm S D s(n=8)$. Different letters indicate significant difference at $P<0.05$ (Duncan test) within shoots and roots, individually.

the rates of photosynthesis and transpiration, stomatal conductance and leaf area etc. (Wang et al., 2005; Ramani et al., 2006). Leaves could accumulate abundant osmoprotectant and adjust their osmotic potential ( $\approx$ leaf water potential) below that of the apoplast and soil in order to ensure that the plants can continue to absorb moisture from the soil and maintain turgor pressure, thus improving their stress tolerance (Bao et al., 2009; Jha et al., 2011; Janz and Polle, 2012; Ma et al., 2012).

Zhang et al. (2010b) reported that GB03 enhanced Arabidopsis choline and glycine betaine synthesis associated with enhanced osmolyte content, resulting in increased plant tolerance to osmotic stress. In the case of white clover, GB03 significantly reduced leaf osmotic potential under severe salt stress conditions $(150 \mathrm{mM} \mathrm{NaCl})$.
Soil salinity is known to increase the level of reactive oxygen species in plant leaves, which are well recognized for membrane lipid peroxidation and cause an increase in leaf malondialdehyde (MDA), a product of membrane lipid peroxidation (Koca et al., 2006; Yazici et al., 2007). Therefore, leaf MDA content, representing the degree of cell membrane damage, is usually used to evaluate plant tolerance to salinity and drought (Luna et al., 2000; Miao et al., 2010). In this work, GB03 significantly decreased leaf MDA content of white clover under saline conditions $(50,100$, and $150 \mathrm{mM} \mathrm{NaCl}$ ).

\section{GB03 REDUCED Na+ CONTENT IN PLANTS}

Saline soils contain a varied and complex array of cation-anion pairs (e.g., $\mathrm{Na}_{2} \mathrm{SO}_{4}, \mathrm{MgSO}_{4}, \mathrm{CaSO}_{4}, \mathrm{MgCl}_{2}, \mathrm{KCl}$, and $\mathrm{Na}_{2} \mathrm{CO}_{3}$ ), with $\mathrm{Na}^{+}$often the dominant species (Zhang et al., 2010a). Growth inhibition, a common plant response to soil salinity, is correlated with high internal $\mathrm{Na}^{+}$concentration and low $\mathrm{K}^{+} / \mathrm{Na}^{+}$ratio in the plant (Zhang et al., 2010a). Plants grown in saline conditions can minimize $\mathrm{Na}^{+}$toxicity by restricting $\mathrm{Na}^{+}$uptake and $\mathrm{Na}^{+}$xylem loading, extruding $\mathrm{Na}^{+}$from root cells and redirecting $\mathrm{Na}^{+}$from shoots to roots (Tester and Davenport, 2003; Munns and Tester, 2008; Zhang et al., 2010a; Kronzucker and Britto, 2011; Zhang and Shi, 2013). Zhang et al. (2008a) found that in Arabidopsis GB03 decreased whole plant $\mathrm{Na}^{+}$content to $54 \%$ of that in control plants by down-regulating HKT1 expression in roots to decrease root $\mathrm{Na}^{+}$ uptake and up-regulating HKT1 expression in shoots to enhance 
shoot-to-root $\mathrm{Na}^{+}$recirculation, respectively. In this study, GB03 soil inoculation significantly decreased $\mathrm{Na}^{+}$accumulation and increased $\mathrm{K}^{+} / \mathrm{Na}^{+}$in both shoots and roots of white clover under salt stress with no measurable effect on $\mathrm{K}^{+}$content in the whole plant. Whether GB03 improves salt tolerance of white clover by tissue specific regulation of $H K T$ gene expression remains to be investigated.

In summary, the results presented here established that the inoculation of the soil bacterium Bacillus subtilis GB03 to the rhizosphere significantly increases plant growth and biomass of the forage legume white clover under both non-saline and saline conditions. GB03-regulated plant processes include chlorophyll abundance, leaf osmotic potential, cell membrane integrity, and ion accumulation. This study provides insight for the application of selected bacteria to cultivated legumes to combat saline toxicity.

\section{ACKNOWLEDGMENTS}

This research was supported by the National Basic Research Program of China (grant No. 2014CB138701), the National Natural Science Foundation of China (grant No. 31172256, 31222053), the Programs for New Century Excellent Talents, Ministry of Education, China (grant No. NCET-11-0217) and the Fundamental Research Funds for the Central Universities (grant No. LZUJBKY-2013-K08, BT05, and 2014-M01).

\section{SUPPLEMENTARY MATERIAL}

The Supplementary Material for this article can be found online at: http://www.frontiersin.org/journal/10.3389/fpls.2014. 00525/abstract

\section{Supplementary Figure 1 | Effects of bacterization on growth of white} clover plants in pots under various concentrations of $\mathrm{NaCl}$. Here GB03 represents Bacillus subtilis GB03 suspension culture in LB medium, LB Luria Broth medium without bacteria and 0, 50, 100, and 150 the concentrations of $\mathrm{NaCl}(\mathrm{mM})$.

\section{REFERENCES}

Acharya, A. R., Wofford, D. S., Kenworthy, K., and Quesenberry, K. H. (2011). Combining ability analysis of resistance in white clover to southern root-knot nematode. Crop Sci. 51, 1928-1934. doi: 10.2135/cropsci2010.12.0695

Bano, A., and Fatima, M. (2009). Salt tolerance in Zea mays (L.) following inoculation with Rhizobium and Pseudomonas. Biol. Fert. Soils 45, 405-413. doi: 10.1007/s00374-008-0344-9

Bao, A. K., Wang, S. M., Wu, G. Q., Xi, J. J., Zhang, J. L., and Wang, C. M. (2009). Overexpression of the Arabidopsis $\mathrm{H}^{+}$-PPase enhanced the salt and drought tolerance in transgenic alfalfa (Medicago sativa L.). Plant Sci. 176, 232-240. doi: 10.1016/j.plantsci.2008.10.009

Barry, C. S. (2009). The stay-green revolution: recent progress in deciphering the mechanisms of chlorophyll degradation in higher plants. Plant Sci. 176, 325-333. doi: 10.1016/j.plantsci.2008.12.013

Bashan, Y., Moreno, M., and Troyo, E. (2000). Growth promotion of the seawaterirrigated oilseed halophyte Salicornia bigelovii inoculated with mangrove rhizosphere bacteria and halotolerant Azospirillum spp. Biol. Fert. Soils 32, 265-272. doi: $10.1007 / s 003740000246$

Battie-Laclau, P., Laclau, J. P., Piccolo, M., Arenque, B., Beri, C., Mietton, L., et al. (2013). Influence of potassium and sodium nutrition on leaf area components in Eucalyptus grandis trees. Plant Soil 371, 19-35. doi: 10.1007/s11104-0131663-7

Cappellari, L. R., Santoro, M. V., Nievas, F., Giordano, W., and Banchio, E. (2013). Increase of secondary metabolite content in marigold by inoculation with plant growth-promoting rhizobacteria. Appl. Soil Ecol. 70, 16-22. doi: 10.1016/j.apsoil.2013.04.001 de Zelicourta, A., Al-Yousif, M., and Hirta, H. (2013). Rhizosphere microbes as essential partners for plant stress tolerance. Mol. Plant 6, 242-245. doi: $10.1093 / \mathrm{mp} / \mathrm{sst} 028$

Diagne, N., Thioulouse, J., Sanguin, H., Prin, Y., Krasova-Wade, T., Sylla, S., et al. (2013). Ectomycorrhizal diversity enhances growth and nitrogen fixation of Acacia mangium seedlings. Soil Biol. Biochem. 57, 468-476. doi: 10.1016/j.soilbio.2012.08.030

Farag, M. A., Ryu, C. M., Sumner, L. W., and Paré, P. W. (2006). GC-MS SPME profiling of rhizobacterial volatiles reveals prospective inducers of growth promotion and induced systemic resistance in plants. Phytochemistry 67, 2262-2268. doi: 10.1016/j.phytochem.2006.07.021

Flowers, T. J. (2004). Improving crop salt tolerance. J. Exp. Bot. 55, 307-319. doi: 10.1093/jxb/erh003

Gray, E. J., and Smith, D. L. (2005). Intracellular and extracellular PGPR: commonalities and distinctions in the plant-bacterium signaling processes. Soil Biol. Biochem. 37, 395-412. doi: 10.1016/j.soilbio.2004.08.030

Gutierrez-Boem, F. H., and Thomas, G. W. (1998). Phosphorus nutrition affects wheat response to water deficit. Agron. J. 90, 166-171. doi: 10.2134/agronj1998.00021962009000020008x

Hayat, R., Ali, S., Amara, U., Khalid, R., and Ahmed, I. (2010). Soil beneficial bacteria and their role in plant growth promotion: a review. Ann. Microbiol. 60, 579-598. doi: 10.1007/s13213-010-0117-1

Hernandez, J. A., Olmos, E., Corpas, F. J., Sevill, F., and Delrio, L. A. (1995). Saltinduced oxidative stress in chloroplasts of pea plants. Plant Sci. 105, 151-167. doi: 10.1016/0168-9452(94)04047-8

Ibragimova, M. V., Rumyantseva, M. L., Onishchuk, O. P., Belova, V. S., Kurchak, O. N., Andronov, E. E., et al. (2006). Symbiosis between the rootnodule bacterium Sinorhizobium meliloti and alfalfa (Medicago sativa) under salinization conditions. Microbiology 75, 77-81. doi: 10.1134/S0026261706 010140

James, R. A., Blake, C., Byrt, C. S., and Munns, R. (2011). Major genes for $\mathrm{Na}^{+}$ exclusion, Naxl and Nax2 (wheat HKT1;4 and HKT1;5), decrease $\mathrm{Na}^{+}$accumulation in bread wheat leaves under saline and waterlogged conditions. J. Exp. Bot. 62, 2939-2947. doi: 10.1093/jxb/err003

Janz, D., and Polle, A. (2012). Harnessing salt for woody biomass production. Tree Physiol. 32, 1-3. doi: 10.1093/treephys/tpr127

Jha, Y., Subramanian, R. B., and Patel, S. (2011). Combination of endophytic and rhizospheric plant growth promoting rhizobacteria in Oryza sativa shows higher accumulation of osmoprotectant against saline stress. Acta Physiol. Plant. 33, 797-802. doi: 10.1007/s11738-010-0604-9

Koca, H., Ozdemir, F., and Turkan, I. (2006). Effect of salt stress on lipid peroxidation and superoxide dismutase and peroxidase activities of Lycopersicon esculentum and L. pennellii. Biol. Plant. 50, 745-748. doi: 10.1007/s10535-0060121-2

Kronzucker, H. J., and Britto, D. T. (2011). Sodium transport in plants: a critical review. New Phytol. 189, 54-81. doi: 10.1111/j.1469-8137.2010.03540.x

Kronzucker, H. J., Coskun, D., Schulze, L. M., Wong, J. R., and Britto, D. T. (2013). Sodium as nutrient and toxicant. Plant Soil 369, 1-23. doi: 10.1007/s11104-0131801-2

Luna, C., Seffino, L. G., Arias, C., and Taleisnik, E. (2000). Oxidative stress indicators as selection tools for salt tolerance in Chloris gayana. Plant Breeding 119, 341-345. doi: 10.1046/j.1439-0523.2000.00504.x

Lunde, C., Drew, D. P., Jacobs, A. K., and Tester, M. (2007). Exclusion of $\mathrm{Na}^{+}$via sodium ATPase (PpENA1) ensures normal growth of Physcomitrella patens under moderate salt stress. Plant Physiol. 144, 1786-1796. doi: $10.1104 /$ pp. 106.094946

Ma, Q., Yue, L. J., Zhang, J. L., Wu, G. Q., Bao, A. K., and Wang, S. M. (2012). Sodium chloride improves photosynthesis and water status in the succulent xerophyte Zygophyllum xanthoxylum. Tree Physiol. 32, 4-13. doi: 10.1093/treephys/tpr098

Mahajan, S., and Tuteja, N. (2005). Cold, salinity and drought stresses: an overview. Arch. Biochem. Biophys. 444, 139-158. doi: 10.1016/j.abb.2005.10.018

Marques, A. P., Pires, C., Moreira, H., Rangel, A. O., and Castro, P. M. (2010). Assessment of the plant growth promotion abilities of six bacterial isolates using Zea mays as indicator plant. Soil Biol. Biochem. 42, 1229-1235. doi: 10.1016/j.soilbio.2010.04.014

Mayak, S., Tirosh, T., and Glick, B. R. (2004). Plant growth-promoting bacteria confer resistance in tomato plants to salt stress. Plant Physiol. Biochem. 42, 565-572. doi: 10.1016/j.plaphy.2004.05.009 
Medeiros, F. H., Souza, R. M., Medeiros, F. C., Zhang, H., Wheeler, T., Payton, P., et al. (2011). Transcriptional profiling in cotton associated with Bacillus subtilis (UFLA285) induced biotic-stress tolerance. Plant Soil 347, 327-337. doi: 10.1007/s11104-011-0852-5

Mhadhbi, H., Jebara, M., Limam, F., and Aouani, M. E. (2004). Rhizobial strain involvement in plant growth, nodule protein composition and antioxidant enzyme activities of chickpea-rhizobia symbioses: modulation by salt stress. Plant Physiol. Biochem. 42, 717-722. doi: 10.1016/j.plaphy.2004.07.005

Miao, B. H., Han, X. G., and Zhang, W. H. (2010). The ameliorative effect of silicon on soybean seedlings grown in potassium-deficient medium. Ann. Bot. 105, 967-973. doi: 10.1093/aob/mcq063

Munns, R., and Tester, M. (2008). Mechanisms of salinity tolerance. Annu. Rev. Plant Biol. 59, 651-681. doi: 10.1146/annurev.arplant.59.032607.092911

Ozawa, T., Wu, J., and Fujii, S. (2007). Effect of inoculation with a strain of Pseudomonas pseudoalcaligenes isolated from the endorhizosphere of Salicornia europea on salt tolerance of the glasswort. Soil Sci. Plant Nutr. 53, 12-16. doi: 10.1111/j.1747-0765.2007.00098.x

Paré, P. W., Zhang, H. M., Aziz, M., Xie, X. T., Kim, M. S., Shen, X., et al. (2011). Beneficial rhizobacteria induce plant growth: mapping signaling networks in Arabidopsis. Biocommun. Soil Microorg. Soil Biol. 23, 403-412. doi: 10.1007/9783-642-14512-4_15

Porra, R. J., Thompson, W. A., and Kriendemann, P. E. (1989). Determination of accurate extinction coefficients and simultaneous equations for assaying chlorophyll $\mathrm{a}$ and $\mathrm{b}$ extracted with four different solvents: verification of the concentration of chlorophyll standards by atomic absorption spectroscopy. Biochim. Biophys. Acta 975, 384-394. doi: 10.1016/S0005-2728(89)80347-0

Rahnama, A., James, R. A., Poustini, K., and Munns, R. (2010). Stomatal conductance as a screen for osmotic stress tolerance in durum wheat growing in saline soil. Funct. Plant Biol. 37, 255-263. doi: 10.1071/FP09148

Ramani, B., Reeck, T., Debez, A., Stelzer, R., Huchzermeyer, B., Schmidt, A., et al. (2006). Aster tripolium L. and Sesuvium portulacastrum L.: two halophytes, two strategies to survive in saline habitats. Plant Physiol. Biochem. 44, 395-408. doi: 10.1016/j.plaphy.2006.06.007

Rengasamy, P. (2010). Soil processes affecting crop production in salt-affected soils. Funct. Plant Biol. 37, 613-620. doi: 10.1071/FP09249

Rogers, M. E., Noble, C. L., Halloran, G. M., and Nicolas, M. E. (1997). Selecting for salt tolerance in white clover (Trifolium repens): chloride ion exclusion and its heritability. New Phytol. 135, 645-654. doi: 10.1046/j.1469-8137.1997.00685.x

Rudrappa, T., Biedrzychi, M. L., Kunjeti, S. G., Donofrio, N. M., Czymmek, K. J., Paré, P. W., et al. (2010). The rhizobacterial elicitor acetoin induces systemic resistance in Arabidopsis thaliana. Commun. Integr. Biol. 3, 130-138. doi: 10.4161/cib.3.2.10584

Ryu, C. M., Farag, M. A., Hu, C. H., Reddy, M. S., Kloepper, J. W., and Paré, P. W. (2004). Bacterial volatiles induce systemic resistance in Arabidopsis. Plant Physiol. 134, 1017-1026. doi: 10.1104/pp.103.026583

Stein, T., Borchert, S., Conrad, B., Feesche, J., Hofemeister, B., Hofemeister, J., et al. (2002). Two different lantibiotic like peptides originate from the ericin gene cluster of Bacillus subtilis A1/3. J. Bacteriol. 184, 1703-1711. doi: 10.1128/JB.184.6.1703-1711.2002

Tester, M., and Davenport, R. (2003). $\mathrm{Na}^{+}$tolerance and $\mathrm{Na}^{+}$transport in higher plants. Ann. Bot. 91, 503-527. doi: 10.1093/aob/mcg058

Tiwari, S., Singh, P., Tiwari, R., Meena, K. K., Yandigeri, M., Singh, D. P., et al. (2011). Salt-tolerant rhizobacteria-mediated induced tolerance in wheat (Triticum aestivum) and chemical diversity in rhizosphere enhance plant growth. Biol. Fert. Soils 47, 907-916. doi: 10.1007/s00374-011-0598-5

Tuna, A. L., Kaya, C., Higgs, D., Murillo-Amador, B., Aydemir, S., and Girgin, A. R. (2008). Silicon improves salinity tolerance in wheat plants. Environ. Exp. Bot. 62, 10-16. doi: 10.1016/j.envexpbot.2007.06.006

van Hulten, M., Pelser, M., van Loon, L. C., Pieterse, C. M., and Ton, J. (2006). Costs and benefits of priming for defense in Arabidopsis. Proc. Natl. Acad. Sci. U.S.A. 103, 5602-5607. doi: 10.1073/pnas.0510213103
Wang, L. W., Showalter, A. M., and Ungar, I. A. (2005). Effects of intraspecific competition on growth and photosynthesis of Atriplex prostrata. Aquat. Bot. 83, 187-192. doi: 10.1016/j.aquabot.2005.06.005

Wang, S. M., Zhang, J. L., and Flowers, T. J. (2007). Low-affinity $\mathrm{Na}^{+}$ uptake in the halophyte Suaeda maritima. Plant Physiol. 145, 559-571. doi: 10.1104/pp.107.104315

Xie, X., Zhang, H., and Paré, P. W. (2009). Sustained growth promotion in Arabidopsis with long-term exposure to the beneficial soil bacterium Bacillus subtilis (GB03). Plant Signal Behav. 4, 948-953. doi: 10.4161/psb.4.10.9709

Yazici, I., Tuerkan, I., Sekmen, A. H., and Demiral, T. (2007). Salinity tolerance of purslane (Portulaca oleracea L.) is achieved by enhanced antioxidative system, lower level of lipid peroxidation and proline accumulation. Environ. Exp. Bot. 61, 49-57. doi: 10.1016/j.envexpbot.2007.02.010

Zayed, M. A., and Zeid, I. M. (1998). Effect of water and salt stresses on growth, chlorophyll, mineral ions and organic solutes contents, and enzymes activity in mung bean seedlings. Biol. Plant. 40, 351-356. doi: 10.1023/A:1001057728794

Zhang, H., Kim, M. S., Krishnamachari, V., Payton, P., Sun, Y., Grimson, M., et al. (2007). Rhizobacterial volatile emissions regulate auxin homeostasis and cell expansion in Arabidopsis. Planta 226, 839-851. doi: 10.1007/s00425-007-0530-2

Zhang, H., Kim, M. S., Sun, Y., Dowd, S. E., Shi, H., and Paré, P. W. (2008a). Soil bacteria confer plant salt tolerance by tissue-specific regulation of the sodium transporter HKT1. Mol. Plant Microbe Interact. 21, 737-744. doi: 10.1094/MPMI-21-6-0737

Zhang, H., Murzello, C., Sun, Y., Kim, M. S., Xie, X., Jeter, R. M., et al. (2010b). Choline and osmotic-stress tolerance induced in Arabidopsis by the soil microbe Bacillus subtilis (GB03). Mol. Plant Microbe Interact. 23, 1097-1104. doi: 10.1094/MPMI-23-8-1097

Zhang, H., Sun, Y., Xie, X., Kim, M. S., Dowd, S. E., and Paré, P. W. (2009). A soil bacterium regulates plant acquisition of iron via deficiency-inducible mechanisms. Plant J. 58, 568-577. doi: 10.1111/j.1365-313X.2009.03803.x

Zhang, H., Xie, X., Kim, M. S., Kormyeyev, D. A., Holaday, S., and Paré, P. W. (2008b). Soil bacteria augment Arabidopsis photosynthesis by decreasing glucose sensing and abscisic acid levels in planta. Plant J. 56, 264-273. doi: 10.1111/j.1365-313X.2008.03593.x

Zhang, J. L., Flowers, T. J., and Wang, S. M. (2010a). Mechanisms of sodium uptake by roots of higher plant. Plant Soil 326, 45-60. doi: 10.1007/s11104-009-0076-0

Zhang, J. L., and Shi, H. Z. (2013). Physiological and molecular mechanisms of plant salt tolerance. Photosynth. Res. 115, 1-22. doi: 10.1007/s11120-013-9813-6

Zhang, N., Wu, K., He, X., Li, S. Q., Zhang, Z. H., Shen, B., et al. (2011). A new bioorganic fertilizer can effectively control banana wilt by strong colonizaton with Bacillus subtilis N11. Plant Soil 344, 87-97. doi: 10.1007/s11104-0110729-7

Conflict of Interest Statement: The authors declare that the research was conducted in the absence of any commercial or financial relationships that could be construed as a potential conflict of interest.

Received: 19 August 2014; accepted: 16 September 2014; published online: 08 October 2014.

Citation: Han Q-Q, Lü X-P, Bai J-P, Qiao Y, Paré PW, Wang S-M, Zhang J-L, Wu Y$N$, Pang $X-P, X u W-B$ and Wang Z-L (2014) Beneficial soil bacterium Bacillus subtilis (GB03) augments salt tolerance of white clover. Front. Plant Sci. 5:525. doi: 10.3389/ fpls.2014.00525

This article was submitted to Plant Physiology, a section of the journal Frontiers in Plant Science.

Copyright (c) 2014 Han, Lü, Bai, Qiao, Paré, Wang, Zhang, Wu, Pang, Xu and Wang. This is an open-access article distributed under the terms of the Creative Commons Attribution License (CC BY). The use, distribution or reproduction in other forums is permitted, provided the original author(s) or licensor are credited and that the original publication in this journal is cited, in accordance with accepted academic practice. No use, distribution or reproduction is permitted which does not comply with these terms. 